\title{
Adolescent right axillary accessory breast with galactorrhoea
}

\author{
Ramnik V Patel, ${ }^{1,2}$ Dhaval Govani, ${ }^{3}$ Rasila Patel, ${ }^{4}$ Bhaumik Bhayani ${ }^{5}$
}

${ }^{1}$ Department of Paediatric Urology, University College London Hospitals NHS Foundation Trust, London, UK ${ }^{2}$ Department of Paediatric Urology, Great Ormond Street Children Hospital NHS Trust London, UK

University of Birmingham Medical School, Birmingham, UK

${ }^{4}$ Department of Alternative Medicine, PGICHR, Rajkot, Gujarat, India

${ }^{5}$ Department of Plastic Surgery, PGICHR, Rajkot, Gujarat, India

\section{Correspondence to}

Ramnik V Patel,

ramnik@doctors.org.uk

Accepted 17 March 2014

\section{DESCRIPTION}

A 16-year-old girl presented with a history of tender, subcutaneous mass lesion in the right axilla with a nipple-like projection in the centre of it since birth. She had menarche at the age of 13 years and since then has this axillary mass lesion which used to become prominent during each menstrual period with some discomfort and soreness on touch. Subsequently, she noticed milky discharge from the nipple especially on pressure over the mass lesion. On examination, an elastic, firm, lobulated and well-demarcated subcutaneous mass $3.5 \times 2.5 \mathrm{~cm}$ in size was found in the right axillary fossa and a wellformed nipple was seen over it. On compression, a drop of milky discharge was visible at the tip of the nipple (figure 1). An ultrasound scan confirmed it to be an accessory breast tissue. Fine-needle aspiration biopsy showed mammary gland tissue. She wanted its removal due to concerns about the periodic discomfort, cosmesis and embarrassing milk discharge. She underwent excision uneventfully. Histopathological examination confirmed it to be accessory breast tissue with a well-formed nipple. She had excellent cosmetic result. Accessory mammary tissue with or without a nipple is due to embryological non-regression of the mammary ridges which are located along the mammary line extending from axilla to pubic region. ${ }^{1}$ An accessory nipple may be interpreted as a warty lesion and excised. Awareness about the possibility of accessory nipple and/or breast could avoid such a mishap. ${ }^{2}$ Accessory breast associated with galactorrhoea is very rare in an adolescent. $^{3}$

\section{Learning points}

Accessory nipple and/or breast is rare and possible due to failure of regression of the mammary ridge which extends from axilla to central perineum in a ' $v$ '-shaped fashion.

- Accessory breast tissue may become prominent during ovulation, menstruation, pregnancy, delivery and lactation period and is subject to same pathology as native normal breasts.

- Galactorrhoea is an embarrassing symptom in an adolescent-associated discomfort and cosmetic effects and the inability to wear sleeveless clothes, and an excision may help with excellent cosmetic results.

Contributors RVP, DG, RP and BB have made substantial contributions to the conception and design of this paper, search of literature, the acquisition, analysis and interpretation of the data, to draft the article or revise it critically for important intellectual content, and to the final approval of the version to be published.

Competing interests None.

Patient consent Obtained.

Provenance and peer review Not commissioned; externally peer reviewed.

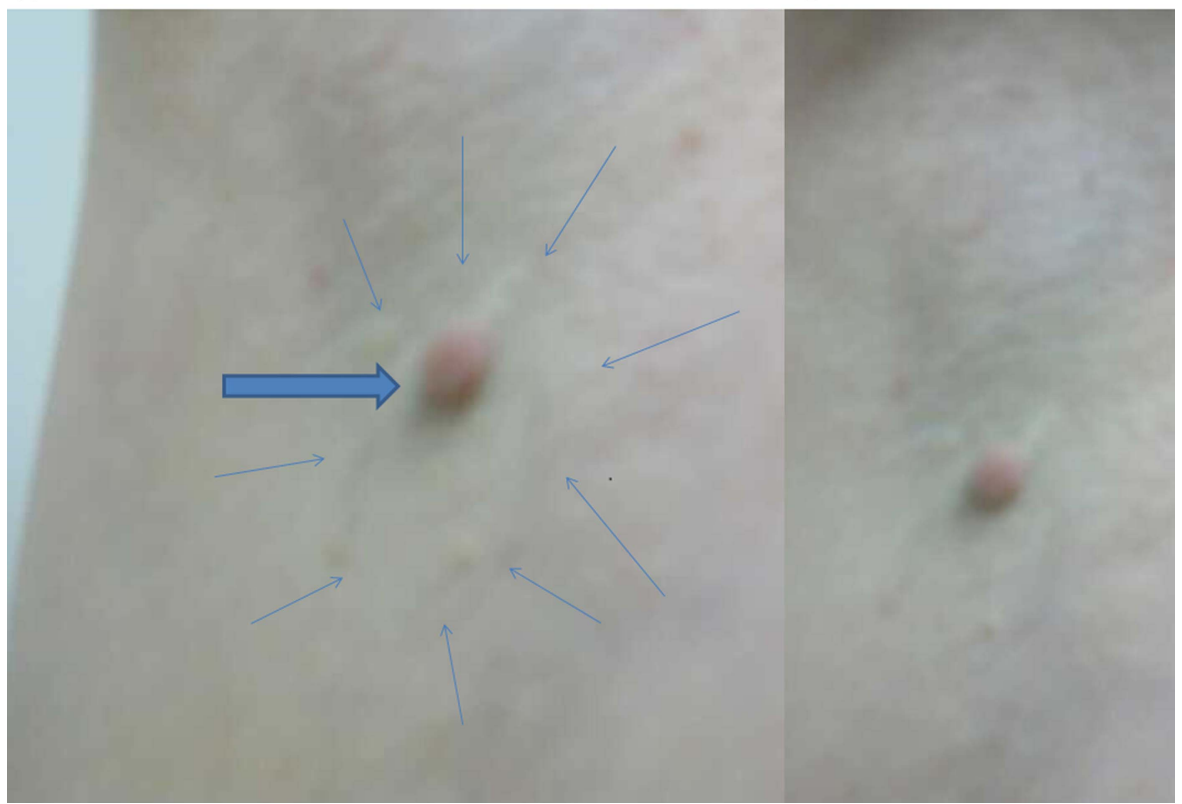

Figure 1 (A) Clinical photograph showing well-formed nipple with a distinct mass (thin arrows) —note a drop of milky discharge at the tip of nipple (big arrow). (B) Close up view showing well developed nipple and diffuse mass underneath 


\section{REFERENCES}

1 Patel RV, Bouhadiba N, Shawis R, et al. Breast at back passage-neonatal central perineal accessory breast at the site of an imperforate anus. BMJ Case Rep. Published online: 10 Feb 2014. doi:10.1136/bcr-2013-203009
2 Patel RV, Govani D, Prajwala R, et al. Bilateral axillary accessory breasts masquerading postnatal axillary abscesses. [submitted to BMJ Case Rep].

3 Kyo A, Oka M, Sasaki Y, et al. Axillary accessory breast associated with galactorrhea in an adolescent girl. Dermatoendocrinology 2010;2:39-40.

Copyright 2014 BMJ Publishing Group. All rights reserved. For permission to reuse any of this content visit

http://group.bmi.com/group/rights-licensing/permissions.

BMJ Case Report Fellows may re-use this article for personal use and teaching without any further permission.

Become a Fellow of BMJ Case Reports today and you can:

- Submit as many cases as you like

- Enjoy fast sympathetic peer review and rapid publication of accepted articles

- Access all the published articles

- Re-use any of the published material for personal use and teaching without further permission

For information on Institutional Fellowships contact consortiasales@bmjgroup.com

Visit casereports.bmj.com for more articles like this and to become a Fellow 